\title{
Welcome guests: settlements of Sinhalese IDPs and local integration process in Sri Lanka
}

\author{
Shantha Wanninayake \\ Department of Sociology, Faculty of Arts, University of Peradeniya, Peradeniya, Sri Lanka.
}

\begin{abstract}
Three decades of civil conflict in Sri Lanka that broke out between the government security forces and the Liberation Tigers of Tamil Eelam (LTTE) in the early 1980s came to an end in 2009. Although more than one decade has passed since ending the civil conflict between them, Sri Lanka is still suffering many multi-faceted issues and challenges concerning the integration of resettled people in the post-conflict resettlement process. This study aims to examine the process of settlement, and the local integration process, as a solution for the settlement issue rather than return and resettlement into the original villages of the Sinhala Internally Displaced People (IDPs) in the northern part of Sri Lanka. As for its empirical evidence, the study is based on qualitative methods. The study areas were selected within the districts of Anuradhapura and Vavuniya. The research finds that there is no one single reason that affected the integration of both communities; IDPs and hosts, but rather a combination of several socio-economic key factors. The study illustrates that the displacements and their settlements show innovation with their integration process rather than marginalisation from the host communities.
\end{abstract}

Keywords: Displacement, settlement, IDPs, integration, host community.

\section{INTRODUCTION}

The protracted armed conflict between the government forces and the Liberation Tigers of Tamil Elam (LTTE) ended in May 2009. It is estimated that the civil war in Sri Lanka claimed the lives of more than 100,000 people and uprooted more than one million people, often several times, with the large majority internally displaced in the island. It has been estimated that up to 1.7 million people were displaced at different periods between 1983 and 2009 (Brun, 2003; Kelegama, 2011; Wickramasinghe, 2009; IDMC, 2016; Chattoraj, 2019). Soon after hostilities ended, the government of Sri Lanka started an accelerated programme to resettle these Internally Displaced People (IDPs). Various processes in the post-conflict context, including IDP resettlement, development and state-building have proceeded within this framework (Kelegama, 2011; Wanninayake, 2017).

Related to Sri Lanka's situation, where they have entered into the post-war phase, IDP issues are considered a vital factor in their peace building, development and reconstruction processes. According to some studies regarding the resettlement and reconstruction process of the country, certain resettlement issues remain unsettled (Kelegama, 2011; Senanayake, 2011). Early in the civil war, the Sri Lankan Government policy was voluntary resettlement, and no compulsion was exerted to resettle the IDPs. They were at liberty to choose the proper time for resettlement. If they did not wish to resettle, they stayed in the Welfare Centers (WCs) or self-settled with host communities, and the government had to look after their needs. After the end of the civil conflict, the government embarked on an ambitious program of resettlement and reconstruction. The government and other organisations initially paid some attention to the IDPs return and resettlement; however, with time, they changed their position with regard to resettlement, self-

"Corresponding author (shanthaw2003@yahoo.com; (D) https://orcid.org/0000-0002-6445-6985)

\footnotetext{
This article is published under the Creative Commons CC-BY-ND License (http://creativecommons.org/licenses/ by-nd/4.0/). This license permits use, distribution and reproduction, commercial and non-commercial, provided that the original work is properly cited and is not changed anyway.
} 
settlement, and relocation of the IDPs. Specifically, the Government of Sri Lanka implemented some programs (Uthuru Wasanthaya \& Neganahira Udanaya) that provided incentives for the IDPs to return to their original villages. However, in reality, the prevailing environment discouraged this return. Return was not always possible or even desired by the IDPs. It depended on the situation in both the original villages and the host communities (Wanninayake, 2017; Chattoraj \& Gerharz, 2019).

In most of the policy-oriented discussions, attention was focused on repatriation and return of displaced persons, and the resultant policy was to be implemented immediately after the cessation of war. Although arrangements were streamlined to enable the IDPs to return to their original places of residence, their interest to do so appeared to gradually diminish, with a great majority refraining from moving out of their temporary places of residence. Some of them openly expressed their unwillingness to go back (Brun, 2003; IDMC, 2016; Wanninayake, 2016; Chattoraj \& Gerharz, 2019) and the fairly long-term displacement had resulted in their living in the host communities for long periods.

This paper mainly explores the reasons why and how majority of the IDPs were reluctant to go back to their original villages and chose to stay with the host areas/ communities where they had stayed during the conflict period $^{1}$. The paper has provided an empirical analysis on the role of social and economic factors that have encouraged the IDPs to remain with the host community. This study aims to examine the process of self-settlement and the local integration process as a solution for the settlement rather than return and resettlement into their original villages in Sri Lanka. Within this context, the study examines the main factors affecting the integration process, especially the social and economic situation, in order to investigate this central question. The paper explores how the IDPs built social relationships with the host communities and the roles of their kinship, friendship, and other networks in building new lives in the host area. The paper also focuses on economic factors as another important part of the IDP's integration into the host communities. The study considers livelihood and livelihood strategies as economic activities. In sum, this paper establishes how these social and economic factors affected the IDPs' integration with the host community.

\section{METHODOLOGY}

The study has primarily adopted a qualitative approach. The use of a qualitative approach may be important in order to adequately understand the "full richness and complexity" of the refugee experience (Hinchman \&
Hinchman, 1997). The reader is directed to more indepth discussions on some of the common perceptions of qualitative research, which mainly relate to research. Primary qualitative data in this study was collected mainly through interviews, including long interviews and key informant interviews. The aim was to understand the people's thoughts subjectively.

Secondary sources were used to help interpret the primary data. For secondary data, the study used published materials such as books, book chapters, research papers, journal articles, research reports, newspaper articles, and internet resources. All the data offer avenues toward uncovering and understanding the multiple interpretations and meanings of IDPs.

The study areas were within the districts of Anuradhapura and Vavuniya, (see Figure 1), focused mainly on the Sinhalese self-settled IDPs. According to the UNHCR (2009), the displacement number during the period of the ceasefire in 2002-2006 and in 2009 decreased, while the return and resettlement process increased. According to the same source, data pertaining to some displaced persons were compared with data on those who were living in the self-settled locations, and most of them were found to be living in host areas. Jaffna and Mullativu recorded the highest numbers of displaced persons, 63,086 and 61,374, respectively. All of the displaced people in these areas were Tamil. Vavuniya was recorded as the third highest with 46,988 with Sinhala and Muslims (UNHCR, 2009). Vavuniya was the highest Sinhala displaced [18,650 in 2004 (IDMC, 2005)] district and the majority of them had moved to host areas in Anuradhapura during the conflict period.

There were two reasons for selecting Vavuniya and Anuradhapura for field work. One reason was that Vavuniya district had the third highest concentration of IDPs at that time and was the only border district with the highest number of IDPs congregated in the country (UNHCR, 2004; IDMC, 2005). Another reason was that the IDPs accommodated within the Vavuniya district comprised of Sinhala, Tamil, and Muslim ethnic groups, and most of them represent border and threatened villages close to the Sinhala majority border district of Anuradhapura.

By 1985-2009, the Anuradhapura district became a host area where a significantly large number of Sinhala IDPs found self-settlement. Since Vavuniya and Anuradhapura were neighboring districts at one stage, the majority of IDPs went from Vavuniya to the Anuradhapura host areas. The study focused on the northern part of Anuradhapura [Medawachchiya Divisional Secretariat 


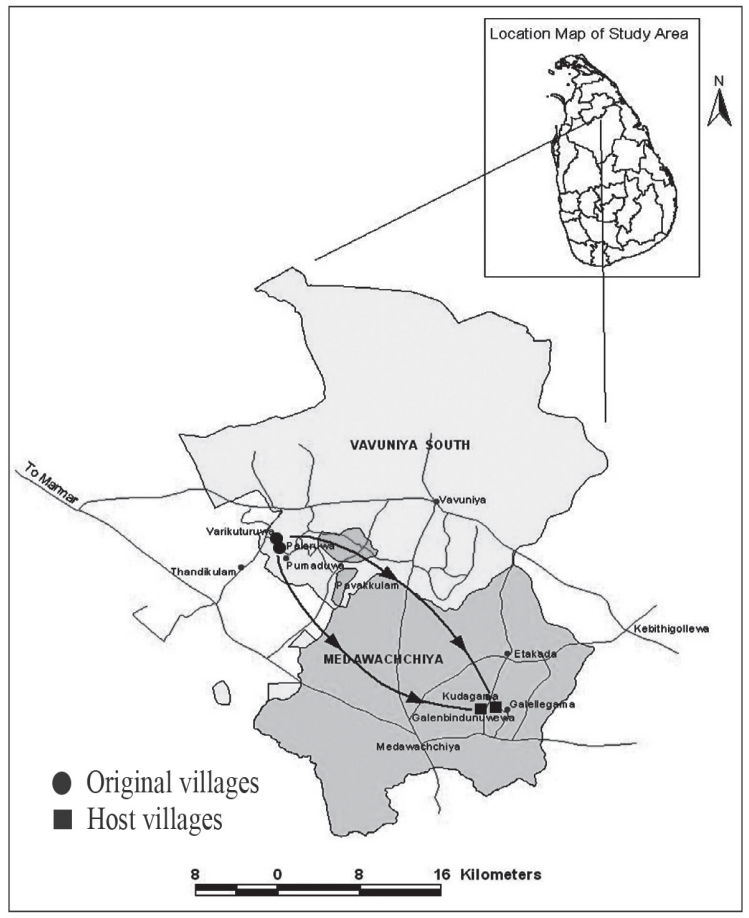

Figure 1: Sinhalese IDPs' original village in Vavuniya South Divisional Secretariat and host villages in Madawachchiya Divisional Secretariat

(DS) as the host area for the IDPs] and Vavuniya- South DS as the original/threatened area from where they were displaced during the civil conflict. Two village locations were selected for the collection of data in the host area. There were 45 families and 24 families which came and settled in village I and village II, respectively ${ }^{2}$. Host village I consisted of 135 families and village II, 81 families during the conflict period (Sri Lanka, Madawachchiya Divisional Secretariat, 2005). The long interviews and key informants interviews were conducted with respondents identified through purposive sampling among IDPs after considering gender, age, occupation and duration of the displacement from the original areas. Fourteen respondents were selected for the interviews from two villages; eight from the village I including key informants, and six from the village II.

This paper focuses attention on Sinhalese IDPs displaced from their threatened villages. This does not mean that the Tamil and Muslim communities were not living in the threatened villages. The majority of the affected communities in this study area were Sinhalese, and also the Sinhalese communities were relatively neglected in accounts of displacement and resettlement process affected by the war.

\section{Durable solutions and internal displacement}

Theories and concepts originally established to address refugee situations can also be used for situations of IDPs. Many studies have been conducted on refugees' settlement, refugee assimilation, integration, repatriation, reintegration and resettlement. Most of the international organisations and policy makers have emphasised the protection of refugee rights and assistance, and they have proposed some solutions for the refugee and displacement problems as a "durable solution". They are called: voluntary repatriation, resettlement in a third country, and local settlement, which was also termed local integration in the country of first asylum. These durable solutions have been developed and promoted by the UNHCR and other agencies. Nonetheless, recent studies and agencies place greater emphasis on seeking a better solution for the refugee problem, and there is a considerable debate regarding these solutions (Jacobson, 2001; Brun, 2003).

The durable solutions were initiated for refugees, but they may also be applied to internally displaced (Bascom, 1998; Brun, 2003; IDMC, 2017). The guiding principles on internal displacement state that return to their homes, integration where they currently reside, or resettlement in another part of the country are the main solutions to the IDP problems. When discussing IDPs, the most accepted solution to the IDP problem is repatriation or return, since most crises of displacement, even protected ones, are regarded as temporary (Jacobsen, 2001; Duncan, 2005). In many cases, such return can only occur when the causes of the displacement have been resolved. However, because of limited situations of safe return, repatriation or return is a poor alternative in many of the protracted conflict situations, which have ended in internal displacement. In fact, the emphasis on repatriation or return as the preferred solution may create false expectations. As this study will show, for IDPs who face situations where repatriation or return is not feasible, there is a need for more long-term solutions like integration with the host community. Because of the policy makers' and Sri Lankan government authorities' focus on repatriation, host community integration has become an almost forgotten solution for refugees and IDPs. This paper attempts to show why host community integration is more important when finding a solution for the displacement problem.

\section{IDPs' integration process and settlement pattern}

In the process of displacement, people who are displaced arrive and settle in a new place, the meeting between the immigrants and the larger society are commonly 
termed 'integration'. Integration is a core concept in social science and it may confusingly mean both a general social process, and the specific outcome of such processes (Favell, 1998). Here, the researcher uses 'integration' as the general process proceeding when migrants and the host community work and live together. Here, the researcher discusses self-settlement and the integration process with the long-term displacement process in Sri Lanka.

Integration as a theoretical concept has its roots going back to the classical sociologists, mainly in Emile Durkheim (Favell, 1998). According to his theory, society is a unity. Durkheim's sociology, basically concerns solidarity between people (Favell, 1998). 'Integration' refers to the relationship between the parts in a society or whole, and solidarity between people makes groups that are more or less integrated depending on to what extent the participants support common concerns (Favell, $1998)^{3}$. For Durkheim integration is a source of vitality because those who are integrated into the larger society gain strength through dealings with others. Therefore, integration may be regarded as strengthening society.

Durkheim's work has been important for understanding how migrants should become part of a society today. Within some other studies, for example, processes of integration have mainly been studied through how immigrant groups have adapted to the host societies in the western world or in America. This tradition owes much to the Chicago School of Sociology for which immigration and its consequences were among the central themes. They published the application of the idea of integration and its use as a conceptual framework for public policies through exploring the spatial relations between ethnic groups and their goals in the early twentieth century (Brun, 2003). One outcome of this view has been the understanding that for immigrants to be accepted in the new society, they have to give up their previous identity and incorporate into the new society. One can apply this view for understanding the Sri Lankan context of the resettlement process.

The researcher defined integration processes as being the policy environment and the willingness of key groups in the host community to accept the displaced people, the livelihood opportunities of hosts and displaced, and the relationship between hosts and displaced people. As the researcher argued above, there is a need for more emphasis on the location where the displaced people settled down. These dimensions will be covered in an analysis of integration processes between the displaced and the hosts in Vavuniya-South and Medawachchiya.
Hence, it should be better understood how the IDPs have already prepared for their settlement in their displacement areas or host communities. According to many researchers and institutions, there are different types of settlement patterns that can be identified among the IDPs, such as self-settlement, assisted settlement, camps or organised welfare centers, local settlement, or relocation (Jacobsen, 2001; Badurdeen, 2010). As a consequence of these different types of settlements and situations, people have dissimilar ideas about their situation of living standards, their willingness to return or stay further in a host area or motivation to settle in a new place. The causal relations for the situation would be that the IDPs would be more attracted toward or pull toward the host community due to their settlement pattern among the host area. For instance, many scholars have shown that the self-settled IDPs are more attracted to the host community/area than camp refugees because of their networks, livelihood situation, and security situation that they have built in the host area (Jacobson, 2001; Hovil, 2007). In the case of Sri Lanka, this study mainly finds that the relationships between the IDPs and the hosts, including the social and economic relationships, are more important when they decide whether to return to their original villages or remain in the host areas and communities.

This article analyses how the categories of host and IDP emerge and develop, and how both locals and displaced take active part in constructing and reconstructing their relationship as hosts and IDPs. The researcher examines how displaced and hosts actively reconstruct their places after their displacement with concerning self-settled IDPs rather than welfare centers and IDPs in the area.

\section{Factors affecting the integration of IDPs to the host community}

Although many studies have been conducted regarding the integration between refugees and the host communities (Chambers, 1986; Kok, 1989; Voutira \& Harrel-Bond, 1995; Whitaker, 2002; Duncan, 2005), rather than on IDPs and the host communities, the models of analyses in those studies can be used for studying the integration between the IDPs and the host communities.

\section{Social and economic factors}

In the 1960s and 1970s, scholars studied the process of chain migration and the role played by the kith and kin in providing information and facilitating migration (see for instance, Hugo, 1981). However, by the late 1980s, the role of social relations in the field of migration turned toward the settlement and integration of people in the 
host countries (Boyd, 1989). There now exists many ways of conceptualising and studying family, kinship, friendship, and community relationship as key factors in international migration.

According to some scholars, social relations with relatives, kin, and friends have played a vital role in providing protection in the process of displacement and settlement (Evans, 2007; Wanninayake, 2017). This role has been augmented during the last couple of decades in the conflict situation, in finding a place to stay. There are various forms of networks formed for material and emotional support during both displacement and settlement. The decision to move to a certain destination or to stay further is affected by the presence of relatives or friends.

Economic relationships and livelihood situation are important and influential factors for the IDPs to determine the place of residence. In this study, economic factors and livelihood include access to land for cultivation and residential purposes, opportunities to continue former occupations, availability of infrastructural facilities, farming and trading, and financial aid and relief. Some studies argue that integration into the host community can be very effective for both IDPs and their hosts, but they argue that this tends to relate only to the specific contexts where the population density is relatively low, implying a labor shortage, where the refugees or IDPs belong to the same ethno-linguistic group as their host community, or where there has been a history of displacement between the original villages and the host communities. In these situations, the refugees or IDPs are able to build adequate livelihoods without generating unnecessary competition with the host community (Brun, 2003; Wanninayake, 2017).

On the other hand, the perceived benefits of regular aid and relief of food and other goods and assistance in the welfare centers can motivate envy in poor host communities (Brun, 2003). Economic suffering among the IDPs is a related concern in many cases of the IDPs settlement in the host communities. Lack of access to arable land is a recurrent factor undermining the livelihoods of displaced people among the hosts. In rural reception areas, this is sometimes mitigated by the capacity of local social and economic structures to provide alternative access to land or other productive resources. (Black \& Sessay, 1997; Leach ,1992).

IDPs who are among the host communities generally survive by sharing the food and resources with the host communities and taking advantage of the income generating opportunities that exist in the host community. This positions the host families and the host community's work as an informal instrument of a humanitarian aid agency or NGO, by saving lives, building flexibility, and providing necessary services. Increasing the support to host families and host communities through suitable and targeted programs can ease the burden of hosting by enhancing their flexibility, decreasing possible tensions, and helping the IDPs to survive. In contrast, it is important to identify when hosting may distort the IDPs and their hosts' livelihood strategies and coping mechanisms and consider ways to avoid this.

\section{EMPRICAL FINDINGS}

\section{Social integration: social relationships among IDPs and hosts}

Building on the increasing recognition is important to examine the social relationship between displaced people and their hosts. When IDPs are welcomed and accepted by the hosts, they will be better able to access livelihoods and other needs without any help from the other parties such as government authorities and other national and international authorities. However, building successful social relationships between the IDPs and the host community will have an impact on their local integration with the hosts and the willingness to stay further and continue their life in the host area/community without returning to the original places.

This research concerns family network, kinship, friendship, and inter-ethnic relationships and link with other institutions in the host areas as social relationship/ networks in the settlement process of the IDPs in the host community. In this research, the researcher considers strong social relationships/networks between the IDPs and the hosts as a factor for integrating IDPs in the host community and, family and kinship relations comprise one of the main social relationships among the IDPs and hosts.

\section{Background factors for the arrival of the IDPs in the host communities}

The field data showed the diverse background factors affecting the arrival of IDPs to the host area. Many Sinhala people from Vavuniya South went to the Medawachchiya division and surrounding villages via their kinship network and stayed with relatives. Around $60 \%$ of them went directly to their relatives' homes. Some other families went to the Vavuniya camp and later became settled in villages in Medawachchiya. Most of them proceeded to the refugee camp at Vavuniya (the Vavuniya Buddhist Temple). The priest of the 
temple allowed them to stay there at the first stage. The government provided them with relief assistance.

Many did not go to the houses of their relatives directly from their native/original village, but some had gone directly to their relatives' villages after being displaced. The first safe places were preliminary stations, and then they prepared themselves and sought to find their resettlement places, finally receiving help from their relatives. People who explained their feelings at that moment said that they got various forms to fill out so they could get the much-needed material and emotional support immediately after displacement at the final settlement or destination. The decision to move, and to which destination, was affected by the nature of the reception from the relatives in the specific destination.

Most of the self-settled IDPs in Medawachchiya reported that they had been well received by the local community at the first stage. Hence, previous relationships with the host community in the safer areas or host areas had affected the IDPs decisions to make a home for themselves.

The protracted civil war and the displacement process took place over a long period of time, and it changed people's status and provided a new environment for them to gain new experiences among the hosts, within the community or the area. The social factor between the IDPs and the host people changed from time to time in accordance with the background situations, which remained in the host area. The socio-economic settings and relationships between the IDPs and the hosts changed, challenging the stereotypical notion of IDPs.

\section{Family, kinship relations and social integration}

As some scholars have shown, international migration of people may operate and link with a broader social field such as the place of origin, in neighboring countries of first asylum, and in the wider diaspora. One of the central aspects of transnational activities is family and kinship networks. Among the extended family or relatives, those who have been displaced or need help may find some support from the link or network of diaspora (Van Hear, 2003; Schulz, 2003). However, this aspect can be used in identifying help among relatives and friends when people are displaced in the context of internal displacement within the country or region. Such a kinship, friendship, and other relationships among the people can be scattered in various places even within the country or region, but the link activates when their needs arise. IDPs who came to Medawachciya area from Vavuniya South showed the role of the family and kinship network among both the IDPs and hosts.

"We could save our lives because we had a place to go. Otherwise, we could have remained in a refugee camp. Thanks to our relatives, today we need not depend on others for our food and other needs. They (relatives) helped us a lot." (Int.1)

The above quotation was given by a middle-aged farmer (later he became the "good farmer" in the area)who migrated with his family and other close relativesfrom Vavuniya South to the Medawachchiya DS in the Anuradhapura district, since they were threatened by the LTTE. He was the eldest son in a family of 12 children. He had seven brothers and five sisters. All were married and had separate families with children in one village in Vavuniya South. His mother had relatives in Medawachchiya and when the conflict began between government forces and Tamil armed groups and created an uncertain environment in the original area, they fled from the village with 45 other families (out of seventy families in the village) in the middle of the1980s and beginning of the 1990s.

This quotation exemplifies how the former kinship relationship played an important role when their relatives faced difficulties and were displaced from their home due to the conflict. However, the role of the family and the kinship network in Medawachchiya, is discussed further below. In the following section, the researcher concentrates more specifically on the bonding of social relationships among the IDPs and hosts in Medawachchiya.

It is widely believed that according to the IDPs settlement pattern and their pre-existing relationship with the host area, it is more important to build and renew the relationship with the host community. Getting help from relatives for accommodation was similarly crucial for the IDPs. However, different relational ties have different degrees of strength. The co-ethnic ties are the weakest while the family bonds are the strongest. Among familial relations, a further differentiation is made between distant relatives and a person's immediate family.

Caste was another factor for forms of networks formed among the IDPs and hosts, another was the caste relationship. This point was echoed by a number of IDP informants as well.

"We have had a blood relationship with the people from this area for a very long time. Then, we 
continued to think of them as 'our people." (Int.1) In general, when the IDPs refer to some as "our people," it means people of the same caste and same kinship group. Support from the relatives has been crucial to many of the IDPs staying in the host community. Providing accommodation, particularly during a desperate situation, is a more important factor than reaching an unknown destination.

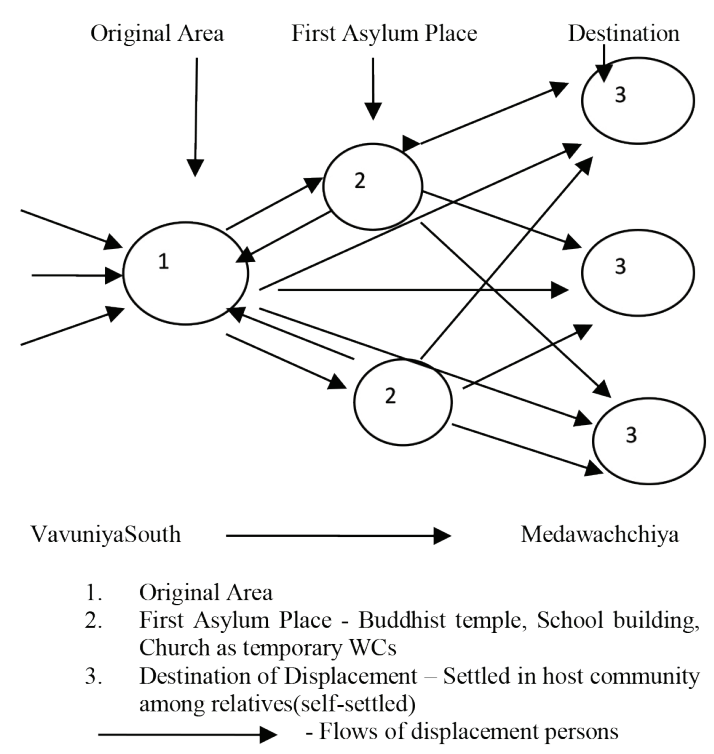

Figure 2: Displacement waves and IDPs settlement process in host villages in the study area

As per Figure 2, some of the IDPs from VavuniyaSouth (No.1) had sought asylum in several different places (No.2), but it was a temporary place because they stay a short period till they find their final destination. and at last (No.3) they found their destination and settled with their hosts. However, some of them had gone directly to their relatives because they had very strong previous relationships with villagers in the Medawachchiya area, (No. 3) after being driven away from their original villages. However, the first asylum places are preliminary stations; it can be called first asylum (no. 2), from where they prepare themselves to find their settlement places (No. 3), finally receiving help from their kinship network.

During the interviews, many informants felt they had close social relationships with the host community and it provided a place to go and settle in the village. Even though they had opportunities to get some relief and assistance from the government and NGOs, they highlighted that the credit should be given to their relatives' role after they came to the host area. According to them, they had benefitted much from their relatives, particularly, in being allowed to stay in the area while providing other assistance that they needed.

\section{Making new social groups}

However, regardless of the nature of the environment that prevailed during the early stages, due to the long period of living in the host community, it had been possible for the IDPs to build various new social relationships with the hosts. During the prolonged stay with the host community, the IDPs had created new social relationships.

Although the support of relatives was a crucial factor for the IDPs to find a place to self-settle, to continue their relationship with newly created relationships became equally or sometimes more important for continuing to live in the area.

"My elder daughter is to be married to a rich family in this area." (Int.1);

"Both my brother and sister are married here (in this village). Even earlier, they were our relatives. We bought a land here.” (Int.9)

Both quotations were given by the self-settled IDPs who have created new relationships with host communities using previous contacts. Respondent (Int.1), as mentioned earlier showed his confidence to stay in the host area with his family without any hesitation. Respondent (Int.9) is a 44 year-old married woman. She is also very self-confident and well established for more than 15 years in the host area having come from Vavuniya South with her extended family. After being displaced from Vavuniya-South they came directly to Medawachchiya and settled down with their distant relatives, but after two years her brother and sister got engaged to be married with two families in the host area. However, it shows newly built relationships between the host community and the IDPs were an important factor for the IDPs to be integrated to the host area and the community. Protracted situations often provide the basic environment to create these types of relationships within the host community. Many IDPs indicated that they had been engaged in new networks within the host community and the area through friendship as well as marriage. Marriage ties are important to build new kinship relations, and it often decides their further residence in a particular place. The study has found that marriage ties are seen to create social expectations and facilitate communication and conflict resolution between IDPs and the host people. 
Due to various other types of objectives, particularly, among the young generation as well as elders, members in both communities formed new social ties. Various types of exchanges and transactions such as food and drinks, labor exchange, etc., have paved the way to build friendly relationships. In addition, through the intervention of government as well as non-governmental organisations, various types of associations were established within the host communities, where both the IDPs and the hosts enjoyed mutual membership. This created a background to increase the frequency of contacts between the IDPs and the hosts. In particular, under the Samurdhi program, there were Shramadanas (collective voluntary activities) and small groups' credit programs where both male and female IDPs and the host community had more opportunities to interact (interview 14). Both government and non-government organisations had organised small group activities that became popular, both among the IDPs and the hosts.

"Now I am a Grama Niladari and a part-time vegetable farmer in this village. I got the idea to grow highland crops from our friends and relatives who came from Vavuniya South... then we worked together with them and we shared our labour and other benefits and we practiced the 'seettu' method for our economic benefits. Generally, when we start a seettu, we can meet more trustworthy people and get together in both our village and the newcomers." (KInt.4)

In this quotation he showed that although it is primarily an economic activity, it generated diverse social relationships. Specifically, mutual trust, goodwill, and friendliness among the IDPs and the hosts were promoted, and these informal relationships became dynamic and meaningful to the individuals interacting with each other. 'Seettu' methods became a very popular method for savings in which both parties were actively involved. Seettu is the traditional system of savings and credit in Sri Lanka. The seettu, a traditional name in Sri Lankan, refers to a contributory savings method popular amongthe people. Although it is primarily an economic activity, it generated diverse social relationships. Specifically, mutual trust, goodwill and friendliness among the IDPs and the hosts were promoted, and these informal relationships became dynamic and meaningful to the individuals interacting with each other.

In addition, voluntary organisations and community development organisations that were formed enabled the promotion of mutual social relationships, goodwill, and discussion among the members. Especially where the self-settled IDPs lived in villages in Medawachchiya such organisations were operational. Sports Clubs, Women's
Associations, 'Young Men's Buddhists Associations,' and 'Death Benevolence Societies' were some examples.

In most rural societies, Death Benevolence Societies are very active voluntary organisations and almost every household is a member. The main reason for its popularity is social security, participation, and cooperation. This type of organisation is essential for each and every family in the event of a death in the area. The Death Benevolence Society does not receive assistance from any government or non-governmental organisation, and its success and strength totally depends on the members.

It appeared that membership in a Death Benevolence Society provided opportunities for increased interactions among the IDPs and members of the host communities. Some of these societies were organised by the IDPs after their arrival in the host community. In one village, the chairman of the Death Benevolence Society was an IDP. In spite of the trivial indifferences as a social group, through their social relationships, networks, and reciprocity, the IDPs and the hosts achieved a complementary relationship, over a period of more than ten years. This trend is visible in almost all the selfsettled villages. The IDPs engaged in performing roles that are uniquely those of the permanent residents of the village. Also, their economic and political relationships have become equal to those of the host community.

\section{Economic integration: livelihood strategies among IDPs and hosts}

Economic relationships and the livelihood situation are important and influential factors for the IDPs' economic integration with the hosts. In this study, economic factors and livelihood include access to land for cultivation and residential purposes, opportunities to continue former occupations, availability of infrastructural facilities, farming and trading, and financial aid and relief. Some studies argue that integration into the host community can be very effective for both refugees and their hosts (Jacobson 2001: Brun, 2003; Wanninayake, 2017).

The majority of the self-settled IDPs in the study area gradually started to buy land and build their own houses in the host area and started to improve their living conditions. However, it was dependent on the extent of the close relationships and integration with the host population.

\section{Land and occupation}

In analysing the livelihood activities in detail, having access to productive land is of great importance to the livelihoods of the IDPs. According to Jacobson (2001), 
"the availability of arable land increases refugees" economic productivity." (Jacobson, 2001: p. 13). As mentioned earlier, although there were some difficulties when some of them were getting land, however, the ones who got access to land, had access to land for building their own houses and some extent of highland for the cultivation of crops.

More than $75 \%$ of the IDPs in the villages had a chance and access to land through using their pre-existing relationships. Some people had rights for access to land through their former kinship relations. Some displaced families were given land free of charge, while others purchased land in the village. But they obtained land at very low prices; they called it "like free of charge". Although there is a law and a legal system for the ownership of land and property in Sri Lanka, traditional land entitlements are also important for access to land in the villages. However, land was the very limited property in the village area as many IDPs settled in the area.

However, after becoming IDPs, some people could re-enter agricultural activities amidst many difficulties within the host community. In addition to landlessness, some other infrastructural facilities were lacking in the host area such as lack of water, lack of capital, taking care of crops (to prevent stealing), transport, and marketing. According to the IDPs, in spite of all these shortcomings, their ability to find some sort of shelter and arable land for them to live on in the host area can be regarded as a significant victory. Also, they felt that some living conditions in the new location had been better than what they had earlier. As one said:

"We were living among innumerable difficulties. Gods sent us here. We recognised that only after coming here; I feel that this is heaven. When compared with the place where we were living, this is much better and I would not leave here." (Int.13)

Above statement was given by a 44-year-old female displaced from Vavuniya-South to Medawachchiya DS and she was the wife of the previous respondent in interview No.1(Int.1). She always helped her husband in his agricultural work. They had arable land in the host village with a house and other properties such as vehicles. It was evident that some of the displaced persons were thinking of their former life and reflected on the present opportunities to engage in their usual occupations and infrastructural facilities as well as other conveniences. Availability of arable land for cultivation and land for residence represented accessibility to former occupations and it symbolised the success of their life, because the main occupation of those who arrived there was farming. Hence, they felt that "God sent us here", "this is heaven". Farmers, arable land, and occupations interlink concepts with one another.

\section{New occupations in the host area}

IDPs who self-settled were used to developing their livelihood or depending on finding new occupations and receiving aid and assistance from the government, NGOs, or INGOS. It was one of the reasons for their integration into the host community. A considerable number of selfsettled IDPs had found new jobs instead of sticking to their former occupations. The majority of the IDPs were farmers, and most of them were experienced marketoriented producers. In addition to cultivating rice, they used to grow vegetables. There were a very few individuals who were small-scale traders in the village, such as being an owner of a boutique or contractor, and some worked as carpenters, fishermen, and government servants. However, almost everyone in the area used to work as a farmer to cultivate paddy and other crops; hence, farming was the main livelihood system in these rural areas making arable land a very important factor for their coping strategy. Some of them had started on new jobs such as being carpenters, fishermen, and small traders in the host area for earning their livelihood. The women were prepared to work as casual labourers as well. A few people have found some unskilled jobs in Medawachchiya town.

\section{Dry rations}

Many people said that they started their new life in the self-settled villages, almost one or two years after being displaced. They did not complain of any difficulties to adjust to the new life in the area. Basically, as they were entitled to receive relief and assistance (dry rations) given by the government and other agencies, it helped them to obtain their consumption needs, to some extent. After about nine (9) months of displacement, they received money from the government for the purpose of building a house. The government had received fixed sums of money from international agencies, to be given to the IDPs in order for them to build a house in their original areas (Sri Lanka, Medawachchiya Divisional Secretariat, 2012).

However, there were many opinions, judgments, and attitudes among the IDPs, some of whom have been having access to their rations for more than 20 years. But many of them, who had received a sum of money as compensation and had started to build their livelihood, have begun their own livelihood strategies without any 
other relief and assistance later on. The IDPs who had taken their total compensation, often commented that their idea was to start their new life through their own efforts in the host areas.

\section{Digging “Agro-Wells"}

"We should be able to earn our own livelihood. If we become dependents on external sources, we would not be able to achieve any progress." (Int.1)

The main challenge was to find land to continue their former occupations. Since the majority of the people were depending on agricultural farming as their livelihood, they had to convert their skills in farming in a proper way to cultivate the highland crop they had received, with experience from the original villages.

The majority of the IDPs who were self-settled farmers indicated a deep interest in working hard, and they had also developed some skills to successfully cultivate highland crops in their former village through the experience of working with the Tamil people in the border areas. The farmers who were in the host area were mostly engaged in chena cultivation as they did not have sufficient water for cultivation of paddy and other highland crops. Under such conditions, the economic conditions within the village were at the lowest level.

However, the arrival of the IDPs into the host area has contributed to change the former socio-economic situation of the host community. One of the respondents explained his role in building the livelihood of the family after their arrival in the area.

"I wanted to lead a new life. My wife helped me a lot in these efforts. I dug a small well, but it was quite deep. But I did not give up. I kept on digging deeper and deeper till the water could be seen in the well" (Int.1).

According to him, the largest challenge for farming in the village was to obtain irrigation water for crop production. He was determined to dig a well with the help of his wife because when they settled in the village, the water stored in the village tank could only be used once in two years for irrigation and that was also only to irrigate the paddy cultivation. Therefore, the first step he took to start farming in the host village was to dig a well to obtain groundwater for cultivation and it was called an 'agro-well'. The introduction of agro-wells to the area was a central point of change in their cultivation methods and strategies.
"When I saw water in the well, I thought that "we had won." I realized that we could move away from poverty. I felt that we had won everything." (Int.1)

Like this family, the majority of self-settled IDPs had considered digging a well as a prerequisite for successful farming due to their past experiences in the original village.

\section{Introducing highland crops}

Most of the successful farmers were those who owned an agro-well and used it to grow crops. The IDPs original villages were an excellent site to cultivate crops such as bananas, chillies, and red onion due to the dry weather conditions in the area. Progressive farmers had invested in the construction of agro-wells. The self-settled IDPs stated that there were virtually no farmers in the host village who recognised the value of an agro-well. At the beginning, digging of the agro-well was not accepted by the host community.

However, as mentioned earlier, the economic situation in the host villages in the study area were relatively poor compared with the other areas until the IDPs came from Vavuniya South and started highland cultivation after digging an agro-well.

The 'best farmer' interviewed above (Int.1) had some skills (they had a practice working with Tamil famers for highland cultivation in their original areas) for successful farming. They started using new methods to grow new crops such as red onions and other highland crops, e.g., cabbage, beetroot, etc., which usually grow well in the wet zone.

However, the most common experience in refugee studies is the economic impact on the host community. Most probably, many host communities consider the arrival of IDPs as a burden, because it is likely that there would be competition for scarce resources such as land, jobs, and other resources, for instance water, firewood, and infrastructure such as schools, housing, and health facilities (Kibreab, 1989; Jacobson, 2001; Duncan, 2005). In the case of the self-settled IDPs in the rural villages in the field area, the picture was different. It created new jobs (buying and selling). The key point is that IDPs are making economic contributions without depending on formal assistance. These situations directly impacted positively on the host community to change their previous attitude and engage with them to continue agricultural work together. 
As a result of these events, many of the host villages and the surrounding areas were developed by highland cultivation, and it has spread even to the paddy lands in the area. It is noteworthy that many respondents pointed out that all the changes in the situation in the area were the result of the arrival of the IDPs in the area. Moreover, some IDPs, who self-settled, contacted formal financial institutions such as "Commercial Bank" and "Rajarata Development Bank" and engaged in transactions to obtain credit to buy high-quality seeds for production.

Some of them (IDPs) engaged withwholesale vegetable dealers at the Manning Market in Colombo. The Manning Market is the main consumer goods market in Colombo. It fulfills both wholesale and retail functions. The growth of these marketing relationships brought about significant changes in the economy of the host village. However, as a result of the IDPs experience and practice, some of the host people improved their farming methods following these systems; thereafter, some of the host farmers started cultivating and got into the vegetable business together with the IDPs. Larger amounts of money were circulating within these villages, and it paved the way for noteworthy changes in the villages. Hence both communities worked together and developed their socio-economic situation and forgot their differences as IDPs and hosts.

According to the people from both communities, after some economic improvement of the IDPs, they became the target of people's attention such as local politicians, Divisional Secretariats and even banks and other agencies lending and investing money. Later, many of the IDPs registered as local citizens in the village proving their residency, but after end of the armed war in 2009, the process was changed and the government, NGOs, and INGOs asked them about their return and resettlement.

\section{CONCLUSION}

Overall, the study has explored the process of selfsettlement and integration in the settlement villages in Medawachchiya DS, Anuradhapura District, Sri Lanka. The study focuses on understanding the socio-economic factors that impact on IDPs integrating into host the community and the area and remaining in the host areas. The study uses qualitative data collection techniques and analysis. The long interview was the main data collection method and in addition, the study used ethnographic observations and key informant interviews to cover background data.

To address the central question, first attention was focused on the social relationships between the IDPs and the host community. The study finds that having preexisting relationships along kin, caste, and friendship ties contributed significantly to finding a potential place to resettle after being displaced. When people started to live in the host community/areas, new relationships were developed between the IDPs and hosts, which further attracted the displaced people to remain in the host area. It became clear that characteristics of homogeneity such as being of the same ethnic group and being a member of the same caste, and kinship relationships, were highly influential in the emergence as well as the strengthening of relationships and their integration process. In particular, the awareness of being relatives before becoming displaced was a factor that accelerated the development of intense relationships, which facilitated early entry to the host community. Also, the kinship relations induced the IDPs to self-settle within the host community. Accordingly, the study found that the kinship relationships had played a major role in enabling the IDPs to self-settle among relatives and live with a satisfactory level of security.

The study found that regardless of the nature of the environment that prevailed during the early stages, due to the extended stays in the host area, it had been possible for the self-settled IDPs to develop various new relationships with the hosts, e.g., new kinship relations such as marriages between the IDPs and host families. In addition, people had developed other relationships such as friends or neighbors in various types of reciprocal relations among themselves. Through interventions by the government as well as NGOs, various types of associations were established within the host community for both the hosts and the IDPs. This created a background to increase the frequency of contacts between the IDPs and hosts.

The economic relations and setting of the IDPs and hosts directly and indirectly influenced to integrate selfsettled IDPs into the host community and the area. The conventional opinion was that displacement generally implied a disruption of social services and social relations, and it resulted in a loss or destruction of livelihoods. In a protected situation, displacement is typically a continuous and indeterminate process (Sorensen, 1998). Hence, displacement does not always represent this uniformity of experience. Long-term displacement and its settlement process cause social dislocation, psychosocial trauma, and marginalisation as well as creates new socio-economic situations among them and the surrounding host area within the host community. The self-settled IDPs feel that the new setting has changed their aspiration to return and resettle even in their original villages. The new setting of both IDPs and hosts created new changes and new positions in the arena of displacement and resettlement process. 
There were several key factors identified by the study regarding the economic relationships of the self-settled IDPs among the hosts, such as the access to land within the host area, the opportunity for the IDPs to engage in some form of employment, the introduction of agrowells, and cultivation of highland crops, the employment of new cropping patterns and activities, and the IDPs had developed linkages with the markets. Almost all the individuals or families focus their attention on the dry rations and other assistance extended to them. Some of the IDPs work for the host community and earn some money for day-to-day living. However, this situation has brought about some economic changes in the area. The land that remained fallow could be cultivated. The workers had been members among the host community who had lost their job opportunities and had to decrease their demand for wages. A patron-client relationship developed between the landlords, businessmen, and the IDP labourers. Accordingly, they helped each other in certain ways. Protracted displacement has continued to exist, and the IDPs and the host community members interacted in different ways, and whether in prosperity or poverty the IDPs adjusted to the existing situation.

The findings of the study indicated that there were different factors that identify in the study to integrate the self-settled IDPs into the host community. It was also observed that the economic relationships were the most dominant, compared to social relationships between the IDPs and the host community. Those who were selfsettled IDPs had used their social relationship such as kinship, caste and friendship relations for arriving at the host community/area and, later through marriages, were able to further strengthen their relationships to a stronger and more powerful state that facilitated them to become permanent residents within the host community/area.

However, based on social relationships, self-settled IDPs initially settled down, but as their entrepreneurial skills pushed them, remained and integrated to the host area due to socio-economic relationships that they had achieved. The IDPs had made a significant contribution to bring about economic advances for themselves, as well as for the host community. This resulted in mutual benefits for both self-settled IDPs and the hosts. As a result, they have emerged as a rich and powerful group. In addition, the host community also gained strength in socio-economic and political capabilities.

Accordingly, this study pointed out that the selfsettled IDPs do not have a further identity as IDPs, as they have become yet another segment of the host community. However, the findings of the study provide evidence to indicate that the majority of self-settled IDPs prefer to live in the host community/area due to many reasons. Accordingly, as a whole the majority of IDPs have gradually adopted and integrated with the host community/area. The findings of this study indicate that with regard to the tendency for integration, they would decide to stay furthermore with new generations. Hence, the study proposes that local integration is still a forgotten solution for IDPs in the case of Sri Lanka and needs to rethinking when creating solutions for resettlement problems.

\section{END NOTES}

1. First part of the study was carried out in the year 2006 for the Doctoral Thesis on Making a Home: Internal Displacement and Resettlement Processes in Sri Lanka 2002-2006 (2017), published by the University of Gothenburg, Sweden. The study was conducted again in 2014 by the author after end of the armed conflict in 2009. The actual host village names are not disclosed with a view of protecting anonymity of the study subjects.

2. Host village names are not given to protect the confidentiality and privacy of the respondents and their villages, but the district and Divisional Secretariats are named with the actual names. For the purpose of the study, the villages shall be named as village I and village II.

3. Durkheim defined two kinds of social integration: mechanical solidarity, the sharing of similar characteristics; and organic solidarity, interdependence based on the division of labour. The former characterised traditional societies, while the latter characterised modern societies.

4. The building of agro-wells in Sri Lanka has been growing steadily since the mid-1980s. The government of Sri Lanka was instrumental in initiating an agro-well development program by providing subsidies for agro-well construction. Agro-well development was seen as a potential source to bridge the gap in the availability of water in dry and intermediate zones of Sri Lanka during the dry seasons (Karunarathne, 2002). In this period there were no facilities or awareness about tube wells.

\section{REFERENCES}

Badurdeen, F. A. (2010) Ending Internal Displacement: The Long-Term IDPs in Sri Lanka, Working Paper Series No. 66, Oxford: Refugee Studies Centre, Oxford Department of International Development, University of Oxford. 
Bascom, J. (1998) Losing Place: Refugee Populations and Rural Transformations in East Africa, New York: Berghahn Books.

Black, R. \& Sessary, M. (1997) Forced Migration, Land Use Change and Political Economy in the Forest Region of Guinea, African Affairs, 96(385), pp: 587-605.

DOI: https://doi.org/10.1093/oxfordjournals.afraf.a007885

Boyd, M. (1989) Family and Personal Networks in International Migration: Recent Development and New Agendas, International Migration Review, 23(3), pp: 638-671.

DOI: https://doi.org/10.2307/2546433

Brun, C. (2003) Finding a Place: Local Integration and Protracted Displacement in Sri Lanka, Trondheim: Norwegian University of Science and Technology, NTNU.

Chambers, R. (1986) Hidden Losers? The Impact of Rural Refugees and Refugee Programs on Poorer Hosts, International Migration Review, 20(2), pp: 245-263.

DOI: https://doi.org/10.1177/019791838602000207

Chattoraj, D. \& Gerharz, E. (2019) Difficult Return: Muslims' Ambivalent Attachments to Jaffna in Post-Conflict Sri Lanka, Working Paper Series 46, Gadong, Brunei: Institute of Asian Studies, Universiti Brueni Darussalam.

Chattoraj, D. (2019) Narratives of Sri Lankan Displaced Tamils Living in Welfare Centres in Jaffna, Sri Lanka, Journal of Maritime Studies and National Integration, 2(2), pp: 67-74.

DOI: https://doi.org/10.14710/jmsni.v2i2.3707

Duncan, C. R. (2005) Unwelcome Guests: Relations between Internally Displaced Persons and Their Hosts in North Sulawesi, Indonesia, Journal of Refugee Studies, 18(1), pp: 25-46.

DOI: https://doi.org/10.1093/jrs/18.1.25

Evans, M. (2007) The Suffering is Too Great: Urban Internally Displaced Persons in the Casamance Conflict, Senegal, Journal of Refugee Studies, 20(1), pp: 60-85.

DOI: https://doi.org/10.1093/jrs/fel026

Favell, A. (1998) Philosophies of Integration: Immigration and the Idea of Citizenship in France and Britain, Basingstoke: Macmillan.

Harrell-Bond, B. E. (1986) Imposing Aid: Emergency Assistance to Refugees, Oxford: Oxford University Press.

Hinchman, L. P. \& Hinchman, S. K. (eds.) (1997) Memory, Identity, Community: The Idea of Narrative in the Human Sciences, New York: State University of New York Press.

Hovil, L. (2007) Self-Settled refugees in Uganda: An Alternative Approach to Displacement?, Journal of Refugee Studies, 20(4), pp: 599-620.

DOI: https://doi.org/10.1093/jrs/fem035
Hugo, G. J. (1981) Village-Community Ties, Village Norms, and Ethnic and Social Networks: A Review of Evidence from the Third World, In G. F. DeJong \& R. W. Gardner (eds.) Migration Decision-Making: Multidisciplinary Approaches to Micro level Studies in Developed and Developing Countries, New York: Pergamon Press, pp: 186-224.

DOI: https://doi.org/10.1016/B978-0-08-026305-2.50013-9

Internal Displacement Monitoring Centre (IDMC) (2005) Internal Displacement: Global Overview of Trends and Developments in 2004, Geneva: IDMC [Online] Available from: https://www.internal-displacement.org/sites/default/files/ publications/documents/2005-global-overview2004-global-en. pdf [Accessed: 24 ${ }^{\text {th }}$ June 2017].

Internal Displacement Monitoring Centre (IDMC) (2017) Internal Displacement: Global Overview of Trends and Developments in 2004, Geneva: IDMC [Online] Available from: https://www.internal-displacement.org/sites/default/files/ publications/documents/2005-global-overview2004-global-en. pdf [Accessed: $27^{\text {th }}$ July 2019].

Jacobsen, K. (2001) The Forgotten Solution: Local Integration for Refugees in Developing Countries, New Issues in Refugee Research, Working Paper No. 45 [Online] Available from: https://www.unhcr.org/research/working/3b7d24059/ forgotten-solution-local-integration-refugees-developingcountries-karen.html [Accessed: 20 ${ }^{\text {th }}$ July 2012].

Kelegama, S. (2011) Socioeconomic Challenges in PostConflict Reconstruction in Sri Lanka, Colombo: Institute of Policy Studies [Online] Available from: https://www.ips.lk/ wp-content/uploads/2017/06/post conflict.pdf [Accessed: $27^{\text {th }}$ July 2017].

Kibreab, G. (1989) Local Settlements in Africa: A Misconceived Option?, Journal of Refugee Studies, 2(4), pp: 468-489.

DOI: https://doi.org/10.1093/jrs/2.4.468

Kibreab, G. (2002) When Refugees Come Home: The Relationship Between Stayees and Returnees in Post-Conflict Eritrea, Journal of Contemporary African Studies, 20(1), pp: 53-80.

DOI: https://doi.org/10.1080/02589000120104053

Kok, W. (1989) Self-settled refugees and the socio-economic impact of their presence on Kassala, Eastern Sudan, Journal of Refugee Studies, 2(4), pp: 419-440.

DOI: https://doi.org/10.1093/jrs/2.4.419

Leach, M. (1992) Dealing with Displacement: Refugee-Host Relations, Food and Forest Resources in Sierra Leonean Mendel Communities during the Liberian Influx, 1990-91, Institute of Development Studies Research Report, No. 22, Sussex: Institute of Development Studies.

Schulz, L. H. (2003) The Palestinian Diaspora: Formation of Identities and Politics of Homeland, London: Routledge. 
Senanayake, D. (2011) Contextualizing post-war transition in Sri Lanka: Growth with militarisation and the logistics of humiliation, In Academy of Fine Arts, Kolkata, Fourth Critical Conference- Development, Logistics, and Governance, Kolkata, India, 8-10 ${ }^{\text {th }}$ September 2011.

Sørensen, B. R. (1996) Relocated Lives: Displacement and Resettlement within the Mahaweli Project, Sri Lanka, Amsterdam: VU University Press.

Sri Lanka, Medawachchiya Divisional Secretariat (2005) Divisional SecretariatReport: ResourceProfileMedawachchiya, Unpublished Statistical Report, Medawachchiya, Sri Lanka: Planning Unit Divisional Secretariat Office.

Sri Lanka, Medawachchiya Divisional Secretariat (2012) DivisionalSecretariatReport:ResourceProfileMedawachchiya, Unpublished Statistical Report, Medawachchiya, Sri Lanka: Planning Unit Divisional Secretariat Office.

UNHCR (2004) Statistical Yearbook Country Data Sheet Sri Lanka [Online] Available from: https://www.unhcr.org/ statistics/STATISTICS/44e5c77611.pdf [Accessed: 20 ${ }^{\text {th }}$ July 2020].

Van-Hear, N. \& Rajasingham-Senanayake, D. (2006) From Complex Displacement to Fragile Peace in Sri Lanka, In: N. van Hear \& C. McDowell (eds.) Catching Fire: Containing Forced Migration in a Volatile World, pp: 45-71, Lanham: Rowman \& Littlefield.

Voutira, E. \& Harrell-Bond, B. E. (1995) In Search of the Locus of Trust: The Social World of the Refugee Camp, In E. D. Valentine \& J. C. Knudsen (eds.) Mistrusting Refugee, pp: 225- 256, Berkeley: University of California Press.

Wanninayake, S. (2017) Making a 'Home': Internal Displacements and Resettlement Processes in Sri Lanka 20022006, Ph.D. Thesis, Sweden: Gothenburg University.

Wanninayake, S. (2016) Finding a Place for Residence; IDPs Remaining With Host Communities: A Case of Sri Lanka, International Journal of Humanities, Arts and Social Sciences (IJHSS), 2(2) April, pp: 80-89.
Whitaker, B. (2002) Refugees in Western Tanzania; the Distribution of Burdens and Benefits among Local Hosts, Journal of Refugee Studies, 15(4), pp: 339-358.

DOI: https://doi.org/10.1093/jrs/15.4.339

Wickramasinghe, N. (2009) Sri Lanka in 2008: Waging War for Peace, Asian Survey, 49(1), pp: 59-65.

DOI: https://doi.org/10.1525/as.2009.49.1.59

Interviewees of the long interviews conducted

\section{Self-settled IDPs - Medawachchiya District Secretariat}

1. Int1. - Farmer, male, 48-year old, self-settled IDP- village I, Medawachchiya.

2. Int2. - Carpenter, male, 38-years, self-settled, IDP- village I/ Medawachchiya.

3. Int3.- Housewife, female, 60-years, self-settled IDPvillage I/Medawachchiya.

4. KInt4.- Key Informant interview, male, Grama Niladari and part time farmer, 45-years, Host-village I/ Medawachchiya.

5. Int6. - Farmer and salesman, male, 30-years, self-settled village I/IDP- Medawachchiya.

6. Int9. - Housewife, female, 44-years old, self-settled IDPvillage II/ Medawachchiya.

7. Int10. - Farmer, male, 40-years, self-settled IDP- village II/ Medawachchiya.

8. Int13. - Housewife, female, 44-years, self-settled IDPvillage II/ Medawachchiya.

9. Int14. - Housewife, female, 60-years, self-settled IDPvillage II/ Medawachchiya. 